University of Chicago Law School

Chicago Unbound

Journal Articles

Faculty Scholarship

1939

\title{
The Present Status of Stock Dividends under the Sixteenth Amendment
}

George F. James

Follow this and additional works at: https://chicagounbound.uchicago.edu/journal_articles

Part of the Law Commons

\section{Recommended Citation}

George F. James, "The Present Status of Stock Dividends under the Sixteenth Amendment," 6 University of Chicago Law Review 215 (1939).

This Article is brought to you for free and open access by the Faculty Scholarship at Chicago Unbound. It has been accepted for inclusion in Journal Articles by an authorized administrator of Chicago Unbound. For more information, please contact unbound@law.uchicago.edu. 


\title{
THE PRESENT STATUS OF STOCK DIVIDENDS UNDER THE SIXTEENTH AMENDMENT
}

\author{
GEORGE F. JAMES*
}

\section{A. THE RESURGENCE OF THE PROBLEM}

I N 1920 the celebrated case of Eisner v. Macomber was decided, holding that the "stock dividends" there involved were not subject to taxation under the Sixteenth Amendment, despite a clear and unmistakable attempt to tax them in the Revenue Act of I9I6. Apparently the general contemporary reaction to the decision was that all stock dividends or none were subject to taxation under the amendment. Certainly the Treasury Department and Congress so assumed, with the result that the I92I Revenue Act provided in section 2OI(d) "A stock dividend shall not be subject to tax ....". Reports of Congressional committees show that this broad and unqualified rule was enacted in the belief that it was necessitated by the decision of Eisner v. Macomber. ${ }^{3}$ So far as appears the more learned commentators anticipated no questions of scope in applying the rule of the Stock Dividend Case. Articles were written on the case by Messrs. Charles E. Clark, ${ }^{4}$ Edward H. Warren ${ }^{5}$ and Eustace Seligman, ${ }^{6}$ with two by Thomas Reed Powell. ${ }^{7}$ Yet of these only Mr. Seligman's considered the scope which should be given the decision in similar but nonidentical situations, and unfortunately his consideration of the problem was distorted by certain misconceptions as to the basis of the majority court opinion. ${ }^{8}$

As a result of this general acceptance of the Eisner-Macomber decision as a rule of broad application covering all dividends paid in the stock of the declaring corporation, there followed for a time a dearth of litigation

* Assistant Professor of Law, University of Chicago Law School.

${ }_{252}$ U.S. 189 (I920); 39 Stat. 756, 757 (I916).

${ }^{2} 42$ Stat. 227,228 (I92I).

3 H.R. 350, 67th Cong., rst Sess. 8 (I92I). Sen. Rep. 275, 67th Cong., Ist Sess. 9 (I921).

4 Clark, Eisner v. Macomber and Some Income Tax Problems, 29 Yale L.J. 735 (I920).

5 Warren, Taxability of Stock Dividends as Income, 33 Harv. I. Rev. 885 (1920).

${ }^{6}$ Seligman, Implications and Effects of the Stock Dividend Decision, 2x Col. L. Rev. $3^{13}$ (Ig2I).

7 Powell, Stock Dividends, Direct Taxes, and the Sixteenth Ammendment, 20 Col. L. Rev. 536 (1920); Income from Corporate Dividends, 35 Harv. L. Rev. 363 (1922).

${ }^{8}$ Compare 2I Col. L. Rev. 313 (rg2I) with 35 Harv. L. Rev. 363,376 (I922). 
on the taxable status of all such distributions. The law seemed too well settled to require reconsideration. The Treasury Department made no further attempt to tax stock dividends in any form or guise and for several years Eisner v. Macomber was used as a precedent only in the analogous field of exchanges in corporate reorganization-where, incidentally, it had an interesting history which should have and may have warned the alert of its shortcomings as a precedent even in cases where it was deemed to be squarely in point. ${ }^{9}$

The cessation of attempts directly to tax stock dividends, however, did not permanently foreclose inquiry into their status under the Sixteenth Amendment. The very fact of their exemption raised new problems which in time reopened the whole question to judicial consideration. The most immediate problem was the treatment to be accorded the proceeds of sales of dividend stock. It had already been established that the difference between the adjusted cost and the amount received on the sale of a capital asset was constitutionally taxable income. ${ }^{\text {I0 }}$ In the majority opinion in the Macomber case Mr. Justice Pitney stated that if a profit be realized on the sale of dividend stock the profit would be taxable income, and that the same would be true if part of the original stock were sold. This dictum left open the question of computation, particularly the question of the "cost" in each case of the dividend or original stock. The Treasury Department from the first took the position that after a stock dividend the basis for determining gain or loss on a sale of either the original or the dividend stock should be the basis previously attributable to the stock originally held, allocated pro rata between the old and new shares. This position seems clearly consistent with the theory of Eisner v. Macomber that the stock dividend constituted a mere "proliferation" of the shares held.

Another point immediately perceived was that the tax exempt character of stock dividends might be made the basis of an easy method of tax avoidance: tax free distribution of corporate profits in cash might be obtained by the declaration and payment of stock dividends, followed by redemption of part of the outstanding stock in cash. Under the majority

9 United States v. Phellis, 257 U.S. $5_{5} 6$ (I921); Rockefeller v. United States, 257 U.S. I76 (I92I); Cullinan v. Walker, 262 U.S. I34 (I923); Weiss v. Stern, 265 U.S. 242 (I924); Marr v. United States, 268 U.S. 536 ( 1925 ). In the last of these, the Marr case, the government's contention, sustained by the Court, was that a taxable gain was realized upon a corporate reorganization "not only when it (the gain in value) is represented by an interest in a different business enterprise or property, but also when it is represented by an essentially different interest in the same business enterprise or property ...." Id. at $54^{\circ}$.

so Doyle v. Mitchell Bros. Co., 247 U.S. I79 (IgI8). 
of the Revenue Acts ordinary stock redemptions were treated as partial liquidations, resulting in capital gain or loss in the amount of the difference between the redemption price and the basis for gain or loss of the stock so redeemed. ${ }^{\text {II }}$ If the redemption of dividend stock issued for the very purpose of being redeemed were so treated, it would permit very considerable distributions of current profits in cash while indefinitely postponing at least the major portion of the tax in the hands of the distributees. Accordingly, the section of the Revenue Act of I92I which recognized the tax free character of stock dividends also provided that if, after distribution of a stock dividend, the corporation should redeem its stock in such manner as to make the distribution and redemption substantially equivalent to the distribution of a cash dividend, the amount so distributed in redemption should be treated like an ordinary cash dividend. ${ }^{x^{2}}$ The same provision, in more or less the same form, was retained in subsequent acts. ${ }^{13}$

In order to determine whether there was occasion for the application of this section $20 r(d)$ and similar matter in subsequent acts it sometimes became necessary to determine whether a past distribution had been a stock dividend. In cases arising in this manner in 1932 the Board of Tax Appeals stated that a dividend payable in a newly created preferred stock, where only one class of stock was outstanding prior to the dividend distribution, was a stock dividend within the meaning of Eisner v. Macomber. ${ }^{14}$

Although the cases last cited have proved to have some importance as precedents before the Board, a far more important decision resulted from another flank attack upon the principle of the Macomber case. As suggested a few paragraphs above, the logic of the rule exempting stock dividends from income tax suggested that the basis previously attributable for determining gain or loss upon subsequent sale of the original stock be spread between the original and dividend stock. Where the original and the dividend stock were not of the same class the Treasury Department took the position that the cost or other basis was to be prorated according to the value of each class. This regulation of the Treasury was first tested in Tillotson Manufacturing Company. ${ }^{\mathrm{Is}}$ It here appeared that Willys-. Overland Company had declared and paid a dividend in common stock

Ix Revenue Acts of 1918 , I92I, I924, § 201 (c); $\S$ II 5 (c) of all subsequent acts.

I2 Revenue Act of I92I, $\S 20 I$ (d), 42 Stat. 228 (I92I).

${ }_{33}$ Revenue Act of $1924, \S 20 \mathrm{I}(\mathrm{f})$; Act of $\mathrm{Ig}_{226} \S 20 \mathrm{I}(\mathrm{g})$; subsequent acts, $\S \operatorname{II}_{5}(\mathrm{~g})$.

${ }^{4}$ Alfred A. Laun, 26 B.T.A. 764 (1932); Pearl B. Brown, Executrix, 26 B.T.A. 902 (I932). 15 27 B.T.A. 9 I3 (I933). 
upon its outstanding cumulative, non-voting, non-participating preferred, part of the dividend being received by the petitioner as a Willys-Overland preferred stockholder. Later in the same year the petitioner sold part of the preferred stock upon which this dividend had been paid. Additional tax was asserted against the petitioner on the theory that part of the basis of the preferred stock should be allocated to the dividend stock, thus reducing the basis of the original stock and thereby increasing the'profit on the sale of it.

The petitioner admitted that such would be the proper procedure in the case of an ordinary stock dividend, but contended that a distribution of common stock to preferred stockholders was not a stock dividend within the meaning either of Eisner v. Macomber or of section $20 \mathrm{I}(\mathrm{f})$ of the Revenue Act of 1926 , and therefore the principle of spreading the old basis between the old and the dividend stock had no application. ${ }^{16}$

A majority of the Board sustained the petitioner's contention. Reexamining the decision in Eisner v. Macomber, the Board pointed out that there the dividend was in common stock on common stock- "a pure proportional common stock dividend." On such facts the Supreme Court had said that the shareholder received nothing of substance and the corporation parted with nothing, hence there was no income. The Board concluded that the effect on the shareholder rather than the effect on the corporation was the material element, that holders of non-participating and non-voting preferred who receive a distribution of common stock do receive something of substance, and that Eisner v. Macomber had no application to such a case. Finally, the Board concluded that section $201(\mathrm{f})$, previously $20 x$ (d), was merely an enactment of the decision in the Stock Dividend Case, the statute being no broader than the case. It followed that the stock dividend was ordinary income when received, although exempt from normal tax for another reason, and that there was no justification for the Commissioner's action in using it to reduce the basis attributable to the old stock. The decision of the majority of the Board was sustained by the Circuit Court of Appeals in Commissioner v. Tillotson $M f g . \mathrm{Co}^{\mathrm{x}}{ }^{7}$

Although the result of this particular case was adverse to the Treasury Department, the principle that certain types of dividends paid in stock

${ }^{26}$ If the petitioner had been a natural person this contention would have been most unwise, since it would constitute an admission that the common stock distribution was properly subject to surtax in the hands of the distributees. Since petitioner was a corporation no such issue could arise in r926. Dividends at this time were exempt from normal tax in the hands of corporate and individual shareholders alike.

${ }^{27} 76$ F. (2d) 189 (C.C.A. $5^{\text {th }} 1935$ ). 
might not be tax exempt under Eisner v. Macomber and statutory provisions enacted in accordance therewith opened up possibilities of additional tax collection upon which the Department seized with avidity. In every case then pending in which the contention would be favorable to the government, the Commissioner advanced the argument that all stock distributions other than common on common were taxable despite the decision of the Macomber case and despite statutory exemptions of stock dividends from tax.

Shortly thereafter the Circuit Court of Appeals for the Ninth Circuit, in Commissioner v. Koshland, ${ }^{\mathrm{x}}$ was faced with precisely the same problem as that involved in the Tillotson case and decided it the opposite way on the theory that regardless of the scope of the principle of Eisner $v$. Macomber Congress had clearly exempted all "stock dividends" from income tax and that a pro rata distribution of preferred stock to all common stockholders was a stock dividend. The court further held that as long as Congress treated such distributions (whether or not constitutionally "income") like common stock dividends by exempting them from taxation, they should likewise be treated like common stock dividends in determining gain or loss from subsequent sale of either the dividend or the original stock.

Certiorari was granted because of the direct conflict between the Koshland and the Tillotson decisions, and the United States Supreme Court reversed the Circuit Court of Appeals in the Koshland case, ${ }^{19}$ on the theory that the dividend there involved was income within the meaning of the Sixteenth Amendment and that for this reason, whether or not the dividend was taxable under the statute, the Commissioner had no power to transfer part of the basis for computation of gain or loss from the originally held stock, which as to the shareholder was capital, to the dividend stock, which as to the shareholder was income. The Court said: .... We hold that the dividends were income and may not be treated as returns of capital.

.... We give great weight to an administrative interpretation long and consistently followed, particularly when the Congress, presumably with that construction in mind, has reenacted the statute without change. The question here, however, is not merely of our adopting the administrative construction but whether it should be adopted if in effect it converts an income tax into a capital levy:.$^{20}$

The Koshland case thus still left open the question of the scope of statutory exemption in favor of stock dividends. The next year, however,

28 8I F. (2d) 84 I (C.C.A. 9th I935).

${ }^{x 9}$ Koshland v. Helvering, 298 U.S. 44I (1936). $\quad{ }^{20} 298$ U.S. $44 \mathrm{I}, 443$ (1936). 
in Helvering v. Gowran, ${ }^{2 x}$ the Supreme Court put this issue at rest. Here a dividend had been paid in preferred stock on common stock in 1929, and the dividend stock redeemed in the same year. In the Supreme Court the Commissioner presented an alternative theory. First, it was asserted that the dividend of preferred on common was taxable income when received, under Constitution and statute alike. But if the Court should hold that the distribution was tax exempt by statute, still it was income under the Constitution, and therefore under the Koshland case no part of the cost basis of the old stock should be allocated to the new. Hence the new stock had a zero basis and the entire amount received on its redemption was income. The Court held with the Commissioner on his second theory.

The history of the Goveran case illustrates the practical limits upon the importance of the constitutional principle finally announced, as applied to the statutory law then in force. After losing before the Board on its original contention that the issuance and redemption of preferred dividend stock was "equivalent to a cash dividend" under section II $5(\mathrm{~g})$ of the I928 Act, the Department had advanced the theory that the stock dividend was itself taxable despite section $\operatorname{II}_{5}(\mathrm{f})$ under the rule of the Tillotson case, and this contention as well was eventually denied. It was only the fortunate fact that the preferred stock had been issued and redeemed in the same year which made available the third and successful theory, that as constitutional "income" exempt by statute the dividend stock had a zero basis, so that the entire proceeds of redemption constituted income in the year in which the deficiency had been assessed. Under the I928 Act the principle of the Koshland and Gowran cases would result in added taxable income only where stock received as a constitutionally taxable dividend was sold in the taxable year; where the dividend stock was held and the original stock sold taxable income would be reduced, as in the Koshland case.

The real importance of the Koshland and Goveran decisions will be felt under the 1936 and subsequent acts, since the Treasury Department, foreseeing the possible development, obtained from Congress a new statutory rule in the 1936 Act: that stock dividends should be tax exempt in the hands of their recipients only to the extent which the Constitution may require. ${ }^{22}$ This expressly makes the statutory exemption co-terminous with whatever may be left of the constitutional principle of Eisner $v$. $M a c o m b e r$, and the present status of that case becomes a question of very lively practical importance.

${ }^{2 x} 302$ U.S. 238 (1937).

${ }^{22}$ Revenue Act of $1936, \S \mathrm{rr} 5(\mathrm{f})$. 


\section{B. THE CONCEPTUAL ARGUMENTS}

Of all possible stock dividend situations, only three have been passed upon by the courts. It has been held that a dividend paid pro rata in common stock on common stock, only one class of stock being authorized, is not income. ${ }^{23}$ It has been held that a dividend paid in preferred stock on common stock, and a dividend paid in common stock on preferred stock, in cases where both classes of stock were already outstanding and not held in equal proportion, are both income. ${ }^{24}$ There are several different rules under any one of which these three cases might logically be subsumed. In fact two principal schools of thought have developed as to the essential distinction between stock dividends which are income within the meaning of the Sixteenth Amendment and stock dividends which represent "a mere proliferation of capital," constitutionally immune from income taxation under the doctrine of Eisner v. Macomber. One may be called the "Tillotson theory," being the theory based upon the analysis of Eisner v. Macomber contained in Commissioner v. Tillotson, where the scope of the Stock Dividend Case was first sharply limited. The Circuit Court of Appeals there argued that dividends paid in common stock on common stock had been held not to be income for two reasons: because there was no severance of corporate assets, and because the dividend neither increased the intrinsic value of the holdings of the shareholders nor altered the pre-existing proportionate interests of the shareholders inter se. Obviously no dividend, at the instant of declaration or of payment, increases the "intrinsic" value of the holdings of the shareholders en masse. This leaves the situation as stated by the circuit court:

Two tests were thus established for distinguishing a taxable from a non-taxable dividend in stock:

(I) Severance of assets from the corporation, and

(2) Alteration of the pre-existing proportionate interest of the stockholders. ${ }^{25}$

The Tillotson test has been adopted by Paul and Mertens in their standard text on federal income tax, and tentatively by Commerce Clearing House. ${ }^{26}$ As recently as the case of August Horrmann ${ }^{27}$ it appeared to have been fully accepted by the Board of Tax Appeals.

The other rule which has been derived from the Macomber, Koshland 4nd Gowran cases is that the test of constitutionally taxable income in a

${ }^{23}$ Eisner v. Macomber, 252 U.S. I89 (I920).

${ }^{24}$ Koshland v. Helvering, 298 U.S. 44I (1936); Helvering v. Gowran, 302 U.S. 238 (1937).

${ }^{25} 76$ F. (2d) 189 , 190 (C.C.A. $5^{\text {th }}$ r935).

${ }^{26}$ Paul and Mertens, Law of Federal Income Taxation (I934), 382 C.C.H. $\left\{835.05_{5}\right.$ (I938).

${ }^{27}$ August Horrmann, 34 B.T.A. II78 (1936). 
stock dividend is whether the shareholder receives any interest substantially different in character or extent from that previously held. The Treasury Department has apparently, although not quite clearly, adopted this second test. There is some indication that the Department goes to the length of asserting that no stock dividend is tax exempt unless the stock distributed is "of precisely the same character" as that in respect of which the distribution was made, and not then if it disturbs the relative priorities of classes of shareholders. ${ }^{28}$ In the very recent case of Frank $J$. and Hubert Kelly Trust ${ }^{29}$ the Board of Tax Appeals adopted this view, reversing its stand in the Horrmann case.

The difference between the two tests in operation can be illustrated by contrasting the Horrmann and Kelly Trust cases. In the Horrmann case the Board flatly stated, although perhaps it did not hold, that a dividend paid in a new issue of preferred stock pro rata to common stockholders, where prior to the payment of the dividend there is only common stock outstanding, is not income. The following reason was given, quoted from an earlier opinion:

At the moment of change, each shareholder's proportionate rights were absolutely and relatively the same except that each in the same ratio had preferred as well as common shares, a difference without significance here.

In the Kelly Trust case the test of income stated was whether the stockholder received an interest substantially different in character or extent from that previously held, and the Board decided that such a substantially different interest had been received through a stock distribution identical with that discussed in the Horrmann case. Should the result and reasoning of the Kelly Trust case be considered correct there is no place to draw the line short of the requirement that the distributed stock be of precisely the same character as that previously held. Any other distribution gives an interest of different character. And even this does not constitute a complete test. If holders of stock distributed and the stock previously held (although the two are of precisely the same character) enjoy any rights prior to rights enjoyed by other classes of stock, or if they gain any advantage by the distribution relative to holders of other classes, an interest of different extent has been received. ${ }^{30}$ Eisner $v$. Macomber is in effect restricted to a dividend of common stock on common stock with no other (I936).

${ }^{28}$ Treas. Reg. 94; art. II5-7 (1936); 7o Treas. Dec. No. 7 (Int. Rev. 4674), art. II5-3

${ }_{29}$ Frank J. and Hubert Kelly Trust, 38 B.T.A.- (Oct. 25, I938).

${ }^{30}$ Instances of such a distribution would be a dividend paid in preferred stock on preferred stock, or in participating class $B$ on participating class $B$, when there is also a participating class $\mathrm{A}$ outstanding. 
fully participating interest outstanding. Thus the substantial change test limits Eisner v. Macomber as a precedent to its very facts, leaving the rest of the field controlled by the Koshland and Goveran cases; the Tillotson test does the opposite.

Whether Eisner v. Macomber would still be followed if the identical situation were again presented to the Supreme Court, and if so, whether it should be given the broader or the more restricted scope as a precedent, are questions of considerable practical importance to many taxpayers and to the government. To date all judicial discussion has assumed the correctness of the stock dividend exemption principle, and opinions have been written in terms of highly technical and conceptual discussions of the meaning of "income" as defined in past opinions of the Supreme Court, particularly in Eisner v. Macomber. Quite likely the same technique will continue to be followed, and this probability justifies re-examination of the opinion of Eisner $v$. Macomber, in the light of later decisions, to find the best argument which can be made on it in terms of "the artificial reason and judgment of law."

Considered on this level, it seems that the basis of the decision was the idea of "capital" as distinguished from the idea of "income." Capital, the Court said, may be depicted as the land of which income is the crop. Income is the gain derived from capital (or the profit realized on conversion of capital). An increase in the value of capital is still capital and not income. The gain must be severed from the capital before it becomes - income and hence subject to taxation under the Sixteenth Amendment. ${ }^{3 x}$

In common usage the word "capital" is employed, perhaps more often than not, to indicate a certain value rather than a specific item of property. But clearly in Eisner v. Macomber this is not the sense in which the word "capital" is used. The distinction drawn between "capital" and "income" in Eisner v. Macomber, expressly excluding from "income" any "growth or increment of value in the investment" demonstrates that the antithetical term "capital" as used by the Court means a certain property, and not a certain value. For instance, if a man owns a fifty acre farm worth $\$ 10,000$, his "capital" for purposes of the principle of the Stock Dividend Case is not \$ro,000; it is a fee interest in fifty acres of land. Similarly, in the case of corporate stock the shareholder's capital is not a sum of money equal to the fair market value of his shares; it is a certain interest, of a given character and extent, in the business enterprise.

Two cases will illustrate this point. In Lynch v. Hornby ${ }^{32}$ the Court held that a cash dividend, extraordinary in amount and distributed after

$$
{ }_{3 x} 252 \text { U.S. } 189,206 \text { (1920). } \quad 32247 \text { U.S. } 339 \text { (1918). }
$$


March I, I9I3, out of earnings accumulated prior to that date, was subject to income tax in the hands of the shareholder despite the fact that it cut into the March I, I9I3, value of the taxpayer's investment. In Lynch v. Turrish ${ }^{33}$ decided the same day, the Court held that a cash distribution by another corporation, identical except that it was in final liquidation of the corporation, was not subject to income tax. The two cases can be reconciled only on the theory that in the Turrish case the shareholder was recovering his capital, while in the Hornby case he retained his capital. This in turn assumes that by "capital" is meant not the money value of the shareholder's interest on March I, I9 3 , which was impaired in both cases, but rather a certain fraction of ultimate ownership in the corporation, represented by common stock, an interest which might fluctuate in intrinsic or in market value without requiring the conclusion that anything had been added to or taken from the capital. With this content of the word "capital" in Eisner v. Macomber, the phrase "capital asset" may fairly be substituted and may serve to eliminate some ambiguity.

To return to the definition of income, the Court stated that "gain derived from capital" to be income must be something of exchangeable value severed from the capital asset previously owned, not a mere increment in value in that asset. This is the first intimation of the importance of severance of income from capital, an idea which, in greatly altered form, makes up the first branch of the Tillotson test. It was first stated as a general proposition:

Here we have the essential matter: not a gain accruing to capital, not a growth or increment of value in the investment; but a gain, a profit, something of exchangeable value proceeding from the property, severed from the capital however invested or employed, and coming in, being "derived," that is, received, or draven by the recipient (the taxpayer) for his separate use, benefit and disposal; that is income derived from property. Nothing else answers the description..$^{34}$

The application of this principle to Mrs. Macomber's situation is clear. Before the stock dividend she owned a certain capital asset: namely, 2200 shares of the only class of stock in Standard Oil of California, representing $.44 \%$ of the ultimate equity in the corporation, with voting and preemptive rights and all the incidents of stock ownership. After the stock dividend she owned I Ioo more shares of the same class of stock, but the whole 3300 represented $.44 \%$ of the ultimate equity in an unchanged

33247 U.S. 221 (I9I8).

${ }^{34} 252$ U.S. I89, 207 (1920). Italics the Court's. Similarly at p. 2I5, meeting the government's contention that stock dividends measure the extent to which gains accumulated by the corporation have made the shareholder richer, the Court said: ". . . enrichment through increase in value of capital investment is not income in any proper meaning of the term." 
corporation, with all the same rights, neither more nor less. Literally the only difference in her property or rights was that the surplus available for declaration of dividends and hence the likelihood of her position being greatly altered in the future by large distributions of corporate cash or property had been diminished as a result of the increased capitalization. Understandably, the Court was unable to regard this change as the receipt by Mrs. Macomber of anything of exchangeable value severed from her capital asset.

Later in the opinion the Court pointed out that no corporate assets had been distributed to Mrs. Macomber, and that her proportionate interest in the affairs of the corporation had not increased. ${ }^{35}$ If either of these things had happened she would have received something of exchangeable value severed from (i.e., not forming a part of) her capital asset. It does not follow, as was assumed in the Tillotson case, that these two are the only ways in which such severed thing of exchangeable value could be received.

For example, suppose that a corporation having a distributable surplus should elect to capitalize this surplus by an issue of bonds or notes which would then be distributed pro rata to the shareholders. If there were but one class of stock outstanding such a distribution would not alter the proportionate interests of the shareholders inter se. Neither would it constitute a severance and distribution of corporate assets. But in such a case something of exchangeable value, severed from his original capital asset, would be received by each shareholder. Where before the distribution each shareholder owned a certain fractional part of the ultimate equity in the business, after the distribution he would own the same fractional part of the same ultimate equity (decreased in value, of course, as every dividend decreases pro tanto the intrinsic value of the stock) and also a fractional part of a new interest, different in character from his original holdings. ${ }^{36}$ In the only cases in which the point has been presented distribution of bonds or notes to stockholders has been held to constitute a taxable dividend ${ }^{37}$ and probably no one would seriously question the decision today.

Applying the same reasoning to the critical case of a preferred stock 35252 U.S. I89, 210-2II (Ig20).

${ }^{36} \mathrm{Mr}$. Justice Brandeis, using substantially this argument, treated dividends either in bonds or in preferred stock as taxable, making the point in the course of a long, technical and closely argued dissent in Eisner v. Macomber, in which he sought to demonstrate that all stock dividends are logically "income," 252 U.S. 189 , 229 (I920).

37 Doerschuck v. United States, 274 Fed. 739 (D.C.N.Y. r93I); United States v. Fuller, 42 F. (2d) 47 I (D.C. Pa. I930). 
dividend declared and paid on common stock, where before the dividend only common was outstanding, the same result can be reached. Truly, no corporate assets have been distributed and there is no alteration of the proportionate interests of shareholders inter se. But each distributee has his same proportion of voting right and same fractional claim to the ultimate equity in corporate earnings and property, represented by his old common stock. In addition he has a preferred right to earnings and perhaps a limited or conditional voting right represented by his new preferred stock. Either can now be sold without the other, where before any sale of stock must carry all rights pro rata. The fact that all of his new rights were gained at his own expense, being carved out of his own prior interest, is not important. This is true of any dividend where there is but one class of stock, and very obviously so if the dividend be paid in notes or bonds. The stockholder's property, like all property, consists in certain rights, - in the case of stock, rights against the corporation, against fellow stockholders, and against third persons generally. Creation of a bonded debt or of a different, perhaps a prior, class of stock does not necessarily or even ordinarily decrease the number or extent of the rights enjoyed by existing shareholders. ${ }^{38}$ The old capital asset remains, although its value is reduced. Then if the newly created stock or bonds be issued to the old shareholders, at least some new rights are derived thereby. More in the case of bonds or notes than in the case of stock, but some in any case where the new stock is not identical with the old. The value of the new rights is derived from the reduction in value of the old, but they are none the less new rights-a new property interest which can be sold without disturbing the capital asset. Such a distribution meets the test of income stated in Eisner v. Macomber: "something of exchangeable value, .... severed from the capital however invested or employed ...." In a real sense, whether cash, or notes or a new type of stock is distributed the distributee receives something of exchangeable value severed from the capital asset previously owned. It follows that the position of the Treasury Department is well founded. Any distribution of new securities, unless the distributed securities be of precisely the same class as those in respect of which the distribution is made, and unless the distribution leaves unchanged the relative position of holders of different classes of stock, is subject to income tax within the rule of Eisner v. Macomber.

${ }^{38}$ Of course the creation of new liabilities or quasi-liabilities may and probably will reduce the total of rights of the corporation. But these rights, although exercised by or under the authority of the shareholders as a body, are not rights of shareholders individually. Reduction of corporate rights alters the value, not the nature and extent, of each shareholder's capital asset. 
It is not expected that the more sophisticated readers of the foregoing argument will be entirely convinced. Equally technical counter-arguments can be made. The author is as well aware as his reader that any attempt conclusively to settle by legal logic the question whether a given corporate distribution is or is not "income" is foredoomed to failure. ${ }^{39}$ Yet so long as stare decisis continues to be an important principle in the United States Supreme Court, no apology need be made for exercises in the argumentative technique of narrowing or expanding precedent. If the Court is not ready to overrule what has proved to be the mischievous principle of Eisner v. Macomber, it well may be ready to limit it narrowly. The foregoing should show that a respectable lawyer-like argument can be made, consistent with every Supreme Court case dealing either with stock dividends or with the related problems of tax free corporate reorganization, and based upon the language of the majority opinions in these cases, to limit the rule of the Macomber case to its very facts,- - a common stock dividend paid on common stock with no other participating security outstanding.

\section{PROBLEMS OF THE IMMEDIATE FUTURE}

Regardless of the scope to be given to the principle of Eisner v. Macomber, a very wilderness of stock dividend problems still must confront the Treasury Department. In the first place, no action by the Supreme Court in merely limiting existing principles of exemption can clarify the field within the near future. In the very nature of the judicial process involved in limiting a precedent without overruling it some debatable ground is inevitable. If the Kelly Trust case is eventually affirmed, substantially on the theory used by the Board of Tax Appeals, a reasonably simple principle will be established. No stock distributed will be tax exempt if it changes the rights of the shareholder recipient in any substantial manner, either by improving his position relative to other classes of shareholders or by giving him new certificates which evidence new rights against the corporation. Almost any distribution of new securities will come within the second branch of this rule if not within both. Suppose, however, a dividend were declared in a new class $A$ stock upon an existing class $B$, the only difference between the two classes being that the new stock has

39 It is worth remembering that Mr. Justice Brandeis' logical demonstration that even common stock dividends are income, contained in his dissent in Eisner v. Macomber, is no more conclusive than Mr. Justice Pitney's logical demonstration of the contrary. This point was clearly and convincingly made in Mr. Thomas Reed Powell's contemporary article on the Stock Dividend Case, 20 Col. L. Rev. 536, 549 (1920); the present author will not presume to supplement Mr. Powell's discussion on this point. 
no voting rights. Would this difference alone be sufficient to distinguish Eisner v. Macomber? Or suppose the class B and class A stocks were both voting, but the new stock was preferred to the extent of being entitled to a dividend of a certain size before the old, the position of the two to be equalized by a dividend on the inferior class if earnings should prove sufficient, after which both should share equally. Somewhere there must come a point at which differences would be held too slight to justify a distinction, if the principle of Eisner $v$. Macomber is to stand at all. Problems of this sort are not insoluble-but considerable loss in time and expense are involved in settling them by the judical process. In the meantime, the only proper course for the government is to claim everything.

Another principal difficulty in the taxation of stock dividends arises from statute and thus, to some extent, may be due to insufficient care exercised by the Treasury Department itself in making its recommendations to Congress. It will be recalled that shortly after the decision of Eisner v. Macomber established the constitutional exemption of stock dividends, a group of cases dealing with corporate reorganization was decided by the Supreme Court. $4^{\circ}$ These cases vary in detail. United States v. Phellis (a case dealing with the reorganization of the DuPont Company) may be taken as typical. Here a reorganization was carried out by the formation of a new corporation, DuPont Company of Delaware, which took over all of the assets of the existing DuPont Company of New Jersey with the exception of certain cash used to retire first mortgage bonds of the New Jersey company. In exchange the New Jersey company received the entire initial issue of stock of the Delaware company. Part of the Delaware preferred stock was used by the New Jersey company to retire outstanding New Jersey securities. The balance of the Delaware preferred stock was held in the treasury of the New Jersey company. The Delaware common stock was distributed to the New Jersey common shareholders as a dividend. As a result of these operations each common shareholder of the New Jersey company retained his interest in that company (which had become merely a holding corporation for preferred stock of DuPont of Delaware) and received in addition a dividend in Delaware common stock. The Delaware common stock received as a dividend was several times as valuable as the New Jersey stock retained. On this state of facts the Supreme Court held that the entire value of the new Delaware stock distributed was taxable to the recipients

$4^{\circ}$ United States v. Phellis, 257 U.S. I56 (I92I); Rockefeller v. United States, 257 U.S. I76 (I92I); Cullinan v. Walker, 262 U.S. I34 (I923); Weiss v. Stern, 265 U.S. 242 (I924); Marr v. United States, 268 U.S. 536 (I925). 
as a dividend. This case occasioned considerable excitement. The result was felt to be unjust primarily because the tax fell upon the distribution of profits which had accrued to the New Jersey corporation prior to March I, I9r3. As a result of the Phellis case and the similar case of Rockefeller $v$. United States ${ }^{4}$ Congress included in the r92I Revenue Act the first statutory provision for tax free exchanges on reorganization..$^{42}$

It would be beyond the scope of this article to consider at length the history of the statutory provisions for tax free reorganization. It is certainly a fair statement that in recent years these provisions have been an extremely efficacious basis for tax avoidance, and as a result have been a serious problem to the taxing authorities. What is relevant to this article is the fact that the present Revenue Act contains in its reorganization sections provisions which may offer an easy way around any tax on stock dividends. Specifically, section II2(b) (2) of the I93 $_{9} \dot{8}$ Revenue Act provides that no gain or loss shall be recognized if common stock in a corporation is exchanged solely for common stock in the same corporation, or if preferred stock in a corporation is exchanged solely for preferred stock in the same corporation. Such a transaction need not be pursuant to a plan of reorganization to gain tax exemption. Section II2(b) (3) provides that no gain or loss shall be recognized if stock or securities in a corporation a party to a reorganization are, in pursuance of a plan of reorganization, exchanged solely for stock or securities in such corporation or in another corporation a party to the reorganization. The definition of "reorganization" contained in section $\mathrm{II}_{2}$ (g) includes "a recapitalization." On the basis of either section II2(b) (2) or II2(b) (3) it would seem possible to avoid any tax on stock dividends by the comparatively simple process of calling in all outstanding stock of a certain class, formally adopting a resolution providing for "a recapitalization" if section II2(b) (3) is to be invoked, and then reissuing more stock with or without changes in priority or powers. ${ }^{43}$ Apparently the only check would be a possible judicial determination that an exchange of stock essentially equivalent to the distribution of a taxable (stock) dividend would be subject to tax in view of section $\operatorname{II}_{5}(\mathrm{f})$ and despite section II2. Strangely, although the attempt to tax certain stock dividends has been in the Revenue Acts since I936, there is nothing today in act or regulations to form the basis for such a decision.

4257 U.S. 176 (Ig2I).

${ }^{42}$ Revenue Act of I92I, § 202(a).

${ }^{43}$ A recapitalization might not be available for all corporations because of the difficulty of stockholder consent, but it could easily be used by closely held corporations, the very ones in which tax avoiding manipulations are most common. In any case, if the class of stock need not be changed, § II2(b)(2) is available. 
Unless some curious metamorphosis has recently occurred among tax specialists, attempts to obtain the result of a tax free stock dividend under the guise of an exchange of securities may confidently be expected.

The same problems which will embarrass attempts to tax stock dividends under the 1936 and later acts will also arise on attempts to tax gain or loss on dividend stock issued in earlier years - the field in which the Tillotson, Koshland and Goveran cases were decided. Here, as in the simple case of taxing the stock distribution itself, the contention is available that what appears to have been a stock dividend was in fact a recapitalization. If so, the basis of the new stock would be governed by section II3(a) (6) of the 1938 and earlier acts, which provides in effect for spreading the cost basis of the securities given in exchange over the securities received in exchange, instead of giving the new securities a zero basis under the Gozeran decision. Indeed, "this argument might be available under Revenue Acts up to I934, even though outstanding stock had not been recalled and reissued, since these earlier acts expressly permitted the tax free distribution of new stock in reorganization without surrender of the old. 44

Even apart from any contention that a stock dividend might amount to a recapitalization, the question of the basis for gain or loss on the sale of dividend stock is confused by section $\operatorname{II}_{3}$ (b) (I) (D) of the $\mathrm{I}_{93}$ and subsequent acts, which provides as follows:

(b) Adjusted Basis.-The adjusted basis for determining the gain or loss from the sale or other disposition of property, whenever acquired, shall be the basis determined under subsection (a), adjusted as hereinafter provided.

(I) General rule.-Proper adjustment in respect of the property shall in all cases be made-

(D) in the case of stock (to the extent not provided for in the foregoing subparagraphs) for the amount of distributions previously made which, under the law applicable to the year in which the distribution was made, either were tax-free or were applicable in reduction of basis (not including distributions made by a corporation, which was classified as a personal service corporation under the provisions of the Revenue. Act of I918 or I92I, out of its earnings or profits which were taxable in accordance with the provisions of section 2 I 8 of the Revenue Act of IgI8 or I92r).

44 See, for example, Revenue Act of $\mathrm{Ig}_{28} 8$, $\S$ II2(g). The contention suggested above was apparently presented in a brief filed by a tax lawyer acting as "amicus curiae" in the Kelly Trust case, and was denied on the ground that so far as appeared from the record there was no plan of reorganization in that case. The contention was also advanced in $\mathrm{H}$. F. Asmussen et al, 38 B.T.A.-(October 27, 1938). In this case the Board, citing its decision in the Kelly Trust case, held for the Commissioner in a memorandum opinion without reference to the claim of reorganization. 
Wherever stock distribution was made in any year between I93 I and I936, taxpayers who sell their dividend stock. will contend that this statutory section requires allocation of basis between the old and new stock, and that, therefore, the zero basis rule of the Gowran case has no application. On the other hand, taxpayers who sell their original stock and retain their dividend stock may well contend that allocation of basis is prohibited by the Koshland case, where the Supreme Court refused to follow a Treasury Regulation requiring apportionment with language which may justify the argument that a constitutional issue was there passed upon. 45

Another difficult basis question would arise if anyone should sell dividend stock received between March I, I9I3, and January I, I92I. If the stock dividend was not one constitutionally exempt from tax within the principle of Eisner v. Macomber as limited by later cases then it was taxable when received up to its fair market value, since the r92 I Act was the first to contain any statutory exemption. Such stock would presumably be another exception to the zero basis rule of the Gowran case, taking as its basis fair market value as of the date of distribution. It was the fact of statutory exemption from tax and not the mere fact of non-payment which in the Gowran case resulted in the zero basis.

One other collateral problem stemming from the Stock Dividend Case deserves brief consideration. Some years subsequent to the establishment of the tax exempt character of stock dividends, the question arose of the effect of such dividends upon "earnings and profits" accumulated since March I, I9I3, and available for distribution. Since I9I7 Congress has not purported to tax dividends paid out of earnings accumulated prior to the effective date of the Sixteenth Amendment, despite its constitutional power to do so. ${ }^{46}$ However, in order to prevent evasion, the law has required that earnings accumulated since the date of the amendment be distributed before earnings accumulated prior to that date. ${ }^{47}$ On this state of the law the question arose whether the payment of a tax exempt stock dividend would operate to exhaust post-amendment earnings so that pre-amendment earnings could then be distributed tax-free. Most of the cases in which this point was presented have held that stock dividends have no effect upon accumulated "earnings and profits." ${ }^{8}$ But a recent

45298 U.S. 44 I, 445 (I936).

${ }^{46}$ Revenue Act of I9I7, § I2II; Lynch v. Hornby, 247 U.S. 339 (I9r8).

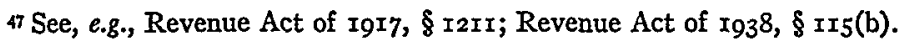

${ }_{48}^{8}$ Walker v. Hopkins, $x_{2}$ F. (2d) 262 (C.C.A. 5 th r926); Nolde v. United States, 64 Ct. Cl.

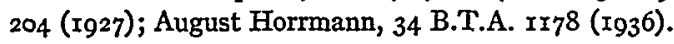


decision of the Circuit Court of Appeals for the Second Circuit has cast doubt on this question, ${ }^{49}$ making it a probable subject for further litigation.

What, if anything, can be done to clear up the present unsatisfactory and confused state of the law? It is submitted that simultaneous pressure for judicial and legislative changes offers considerable hope. On the judicial side, as a minimum, test cases must be pushed to fix the limits of constitutional exemption of stock dividends. This is being done. But more, there is a possibility that the Supreme Court may be ready to reconsider Eisner v. Macomber on the merits. It was a five to four decision, and the membership of the Court has almost entirely changed since it was rendered. Moreover, experience in its application does not commend it. In the first place, no decision so exceptionally fruitful of litigation as the Stock Dividend Case has been can be regarded as an example of good judicial statesmanship, particularly in the field of public revenue. In the second place, as a result of attempts to limit the scope of the original case without overruling it, a situation has been reached in which the exact scope of the constitutional stock dividend exemption can only be defined by the most abstruse logic chopping. Once it was decided in Koshland $v$. Helvering that distribution of corporate assets was not a sine qua non of a taxable dividend, only narrow distinctions and tenuous theory could fill the interstices consistently with precedent. Surely important fiscal questions should not depend upon such refinements. It is submitted that the Supreme Court should be given an opportunity entirely to eliminate the the principle of constitutional tax exemption upon stock dividends. It well may be that if the same case were forcefully presented the present Court would be willing to follow the practical wisdom of Mr. Justice Holmes' dissent in Eisner v. Macomber where he swept across the technical arguments of the majority and of other dissenters alike with the statement:

The known purpose of the Amendment was to get rid of nice questions as to what might be direct taxes, and I cannot doubt that most persons not lawyers would suppose when they voted for it that they put a question like the present to rest. I am of the opinion that the Amendment justifies the tax..$^{50}$

Even this reform, which might be established by the Supreme Court alone, would not remedy the present situation. Action by the Treasury Department is also indicated in clarifying its own regulations and in seeking clarification of the revenue act at the hands of Congress. It is worth

${ }_{99}$ Patty v. Helvering, 98 F. (2d) 717 (C.C.A. 2d r938).

50 252 U.S. I89, 220 (1920). 
noting that the present unsatisfactory state of the law results in no small part from the acceptance by the Treasury Department and the enactment by Congress of an unnecessarily broad view of the scope of Eisner $v$. Macomber. It was only when in the Tillotson case an unusual factual situation made it desirable for the taxpayer to narrow the accepted view of the stock dividend exemption that serious consideration was given to its scope. Today, more than two years after the broad statutory exemption of stock dividends was removed from the Act, apparently no attention has been given to the possible effect of sections II2 and II3. It is to be hoped that a lackadaisical approach by the Treasury will not deprive the government of the benefits which should result from the established limitations upon and from a possible reversal of Eisner v. Macomber.

Specifically, the present section II2(b) (2) might well be removed from the revenue act, the phrase "a recapitalization" excised from section $\operatorname{II} 2(\mathrm{~g})$, and section $\operatorname{II} 2(\mathrm{~b})(3)$ be so rewritten as to make it clear that it has no application to stock dividends or other transactions serving essentially the same purpose, as distinguished from genuine reorganizations of the business of a corporation. The intricate reorganization provisions of the revenue acts have already made enough trouble. If it was good policy to attempt to tax stock dividends by section II 5 of the 1936 and 1938 Acts, it cannot be good policy to render the attempt nugatory through the operation of the tax free exchange clauses of section II2.

Finally, in order to prevent substantial loss of revenue resulting from changing theories of the extent of the taxability of stock dividends, an additional section should be inserted qualifying section $\mathrm{II}_{3}(\mathrm{~b})(\mathrm{I})(\mathrm{D})$ in the next revenue act by providing that any securities heretofore received on a reorganization or through a stock dividend, not in exchange for other securities surrendered, in a transaction on which no tax was paid, should be treated as having a zero basis on any future sale on exchange. The principle is in some ways analogous to that of the "windfall tax" and there seems to be even less reason to doubt its constitutionality.

It is impossible to eliminate all of the confusion and expense caused by unwise judicial decisions and by insufficient imagination and analysis on the part of treasury officials in the past, but following a line of procedure such as that suggested above, in the courts and in Congress, should minimize such troubles in the future. 